\title{
Peak or sustained antibiotic serum levels for optimal tissue penetration
}

\author{
J. P. Thys \\ Département de Médecine Interne, Hôpital Universitaire Saint-Pierre, Université Libre de \\ Bruxelles, Brussels, Belgium
}

\section{J. Klastersky}

Service de Médecine Interne et Laboratoire d'Investigation Clinique H. J. Tagnon, Institut Jules Bordet, Centre des Tumeurs de l'Université Libre de Bruxelles, Brussels, Belgium

\author{
and G. Mombelli
}

Département de Médecine Interne, Inselspital, Berne, Switzerland

\begin{abstract}
A comparative study of the levels of netilmicin in bronchial secretions after intermittent and during continuous intravenous injections was performed. During the first $2 \mathrm{~h}$, the areas under the drug concentration curves in the bolus injection experiment were greater in serum and in bronchial secretions (206 and 150\% respectively) than those associated with the continuous infusion $(P<0.001)$; however, during the $8 \mathrm{~h}$ experimental period, the areas under the curves were similar in serum and bronchial secretions with the two modes of administration. The percentages of penetration of netilmicin from the blood to the bronchial lumen were also similar with the two modes of administration (19\%). After intramuscular administration of amikacin $(7.5$ and $12.5 \mathrm{mg} / \mathrm{kg}$ twice daily), the peak bronchial secretion levels of the drug were 4.4 and $10.1 \mathrm{mg} / \mathrm{l}$ respectively and the trough levels about $1 \mathrm{mg} / \mathrm{l}$. During continuous iv injection of amikacin $(7-12 \mathrm{mg} / \mathrm{kg} / 8 \mathrm{~h})$, the drug level in the bronchial secretions was only $2.0 \mathrm{mg} / \mathrm{l}$ and the percentage of penetration was 14.9\%; adequate anti-Pseudomonas activity in bronchial secretions was rarely achieved. It is therefore suggested that intermittent injections of aminoglycosides can result in at least transitory higher bronchial secretion levels than continuous injection: the intermittent schedule of antibiotic administration could therefore be recommended in the treatment of bronchopulmonary infections since it has been suggested that the concentration of antibiotic in bronchial secretions could be important in the outcome of these infections.
\end{abstract}

\section{Introduction}

With respect to the optimal antibiotic regimen for bronchopulmonary infections, it has been suggested that the concentrations of the antibiotic in bronchial secretions might be of critical importance in the therapeutic outcome of these infections 
(Stewart et al., 1974; Maesen et al., 1976; Klastersky et al., 1979). The bioactive levels of aminoglycosides in bronchial secretions after systemic administration are relatively low when compared to the minimum inhibitory concentration of most Gram-negative bacilli. This could be due mainly to two factors. On one hand, the penetration of the aminoglycosides through the blood/bronchus barrier appears in most studies to be relatively poor. the ratios between the peak bronchial and serum levels are in the range of 10 to 30\% (Pennington \& Reynolds, 1973; Pennington \& Reynolds, 1975; McCrae, Raebum \& Hanson, 1976; Bergogne-Berezin, Even \& Berthelot, 1978). On the other hand, a partial bioinactivation of these antibiotics occurs in purulent sputum: we have shown that the inactivation of netilmicin by sputum may be correlated with the degree of purulence of the secretions (Thys \& Klastersky, 1980a).

Thus it is relevant to study the kinetics of aminoglycosides in bronchial secretions to determine the optimal mode of systemic administration of the antibiotics which could ensure high and sustained bronchial levels, exceeding the MIC of the offending pathogen. In the first part of the present work the penetration of netilmicin into the bronchial secretions after intermittent and during continuous intravenous administration was studied. Bronchial levels of amikacin after intramuscular injection and during continuous infusion were also compared.

\section{Material and methods}

The patients were hospitalized in the Neurosurgical Unit of the Institut Jules Bordet. They presented, at the time of the study, with tracheobronchitis, i.e. purulent bronchial secretions without clinical or radiological signs of parenchymal involvement; in some patients it was associated with bronchopneumonia. All the patients had endotracheal intubation or a tracheostomy and the bronchial secretions, not mixed with saliva, were collected through these routes. The absence of spontaneous antibacterial activity in serum and in bronchial secretions was controlled before each experiment. The samples of serum and bronchial secretions were stored at $-20^{\circ} \mathrm{C}$ until assayed. The assays of netilmicin and amikacin were performed as described by Bennett et al. (1966), using Bacillus subtilis as the test organism. Each assay was made in triplicate. To prepare the reference curves, human serum was used for the serum assays and undiluted supernatant of pooled bronchial secretions obtained by centrifugation $(14,000 \mathrm{rpm}$ during $1 \mathrm{~h})$ for bronchial secretions assays. As far as these latter assays were concerned, we employed the centrifuged supernatant of the bronchial secretions specimens.

Serum and bronchial secretions levels of netilmicin after intermittent and during continuous iv injection

Ten patients were observed in a cross-over study, receiving netilmicin by intermittent and continuous intravenous administration on two consecutive days. The daily dose was $7.5 \mathrm{mg} / \mathrm{kg}$. For intermittent administration, $2.5 \mathrm{mg} / \mathrm{kg}$ (dissolved in $9 \mathrm{ml}$ of $5 \%$ dextrose in water) was injected over a $2 \mathrm{~min}$ period, as a direct bolus injection, three times during a $24 \mathrm{~h}$ period. In the other experiment, the same amount of netilmicin $(7.5 \mathrm{mg} / \mathrm{kg})$ was dissolved in $1000 \mathrm{ml}$ of $5 \%$ dextrose in water and was given as a continuous intravenous infusion using an automated infusion device (Automated Infusion Unit, Decca, London) to control strictly the rate of 
administration. The samples of the serum and bronchial secretions to be studied were obtained between the sixteenth and twenty-fourth hour, that is during the last $8 \mathrm{~h}$, which were considered as a steady-state period. Blood and bronchial secretions samples were obtained just before and at various intervals after bolus injections: $10 \mathrm{~min}, 30 \mathrm{~min}, 1 \mathrm{~h}, 2 \mathrm{~h}, 4 \mathrm{~h}, 6 \mathrm{~h}$ and $8 \mathrm{~h}$. During the $8 \mathrm{~h}$ period of the continuous infusion, samples were taken at $0,2 \mathrm{~h}, 4 \mathrm{~h}, 6 \mathrm{~h}$ and $8 \mathrm{~h}$.

Serum and bronchial secretions levels of amikacin after intermittent and during continuous iv injection

In a first group of six patients, 7.5 and $12.5 \mathrm{mg} / \mathrm{kg}$ were injected intramuscularly twice daily during two consecutive days. Serum and bronchial secretions samples were obtained just before and at $30 \mathrm{~min}, 1 \mathrm{~h}, 2 \mathrm{~h}, 4 \mathrm{~h}, 6 \mathrm{~h}, 8 \mathrm{~h}$ and $12 \mathrm{~h}$ after the injection. Serum and bronchial secretions samples were obtained during the last $12 \mathrm{~h}$ of the experiment which were considered to represent a steady-state period.

The second group of six patients received a loading dose of $4 \mathrm{mg} / \mathrm{kg}$ of amikacin after which 7-12 mg/kg of the drug were continuously infused during $8 \mathrm{~h}$. Two samples of serum were obtained at 2 -h intervals during the last $4 \mathrm{~h}$ of the injection. The inhibitory and bactericidal activity in serum and supernatant of bronchial secretions was measured against ten strains of Pseudomonas aeruginosa (MIC for amikacin $1 \cdot 5-6 \mathrm{mg} / \mathrm{l})$.

\section{Results}

Serum and bronchial secretions levels of netilmicin after intermittent and during continuous iv injection

Levels in serum. After the bolus injection, the mean peak serum level was $12.4 \pm 0.9 \mathrm{mg} / \mathrm{l}$ (mean \pm S.E.) at $10 \mathrm{~min}$ (Thys, Mouawad \& Klastersky, 1979); after 4 and $8 \mathrm{~h}$, the mean serum levels were $2.5 \pm 0.5$ and $1.0 \pm 0.3 \mathrm{mg} / \mathrm{l}$ respectively, as shown in Figure 1. During the continuous infusion, the mean serum level remained stable at $3.3 \pm 0.3 \mathrm{mg} / \mathrm{l}$. During the first $2 \mathrm{~h}$ of the experiment, the area under the curve associated with the bolus infusion was nearly double (206\%) that associated with the continuous injection ( $P<0.001$, Student's $t$-test). However, during the total

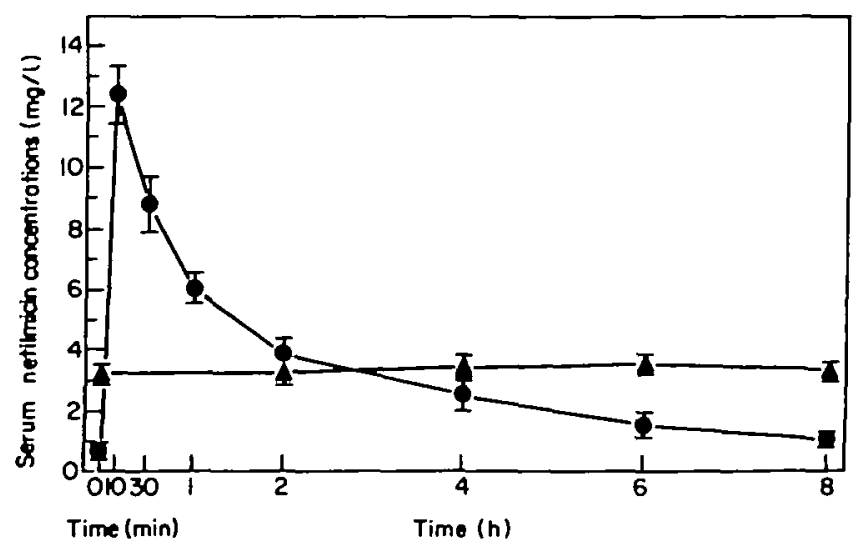

Figure 1. Serum netilmicin levels after bolus injection ( $\bullet$ ) and during continuous infusion ( $(\boldsymbol{\Lambda})$. 
duration of the experiment $(8 \mathrm{~h})$ the areas under the curve with the two modes of administration were similar $(97.5 \%)$.

Levels in bronchial secretions. In the bolus injection experiment, the mean peak of netilmicin in bronchial secretions obtained at $30 \mathrm{~min}$ was $1.1 \pm 0.2 \mathrm{mg} / \mathrm{l}$ as indicated in Figure 2; $4 \mathrm{~h}$ and $8 \mathrm{~h}$ later, the mean bronchial secretions levels were $0.5 \pm 0.1$ and $0.4 \pm 0.1 \mathrm{mg} / 1$ respectively. The mean level during the continuous infusion experiment was $0.6 \pm 0.1 \mathrm{mg} / \mathrm{l}$. As in the serum, the area under the curve in the bolus injection experiments during the first $2 \mathrm{~h}$ was considerably greater $(150 \%)$ than that of the continuous infusion $(P<0.001$, Student's $t$-test) Figure 2; however, there was no difference between the areas under the curves during the 8-h period with the two modes of intravenous administration (96.9\%).

Penetration of netilmicin across the blood bronchus barrier. The percentage of penetration (ratio of the areas under the curves in bronchial secretions and in serum $\times 100$ ) of netilmicin across the blood/bronchus barrier were calculated with the two modes of administration: this percentage calculated during the continuous administration is identical to that observed during the $8 \mathrm{~h}$ of the bolus experiment (19.3\% and $19 \cdot 2 \%$, respectively). However, the penetration during the first $2 \mathrm{~h}$ of the bolus experiment is smaller than that observed during the same period of the continuous infusion $(14.4$ vs. $19 \cdot 7 \%)(P<0.05)$.

Serum and bronchial secretions levels of amikacin after intermittent and during continuous iv injections

Repeated im injections of amikacin. After the im injection of $7.5 \mathrm{mg} / \mathrm{kg}$ of amikacin, the mean peak serum level was $20 \cdot 7 \pm 2 \cdot 7 \mathrm{mg} / \mathrm{l}$ (mean \pm s.E.) (Figure 3) (Thys \& Klastersky, 1980b); 6 and $12 \mathrm{~h}$ later, the mean serum levels were $4.6 \pm 0.9$ and $1.8 \pm 0.8 \mathrm{mg} / \mathrm{l}$ respectively. After the injection of $12.5 \mathrm{mg} / \mathrm{kg}$, the mean peak serum level was $36.2 \pm 5.7 \mathrm{mg} / \mathrm{l}$, and 6 and $12 \mathrm{~h}$ later, the corresponding serum levels were $15.3 \pm 4.7$ and $4.7 \pm 2.4 \mathrm{mg} / \mathrm{l}$ respectively. As far as the amikacin levels in the bronchial secretions are concerned, the mean peak level was $4.4 \pm 0.7 \mathrm{mg} / \mathrm{l}$ after the injection of $7.5 \mathrm{mg} / \mathrm{kg}$ (Figure 3); 6 and $12 \mathrm{~h}$ later, the bronchial levels were $4.1 \pm 1.0$ and $0.9 \pm 0.3 \mathrm{mg} / 1$ respectively. After the injection of $12.5 \mathrm{mg} / \mathrm{kg}$, the mean peak bronchial level was $10.1 \pm 2.2 \mathrm{mg} / \mathrm{l}$; the levels

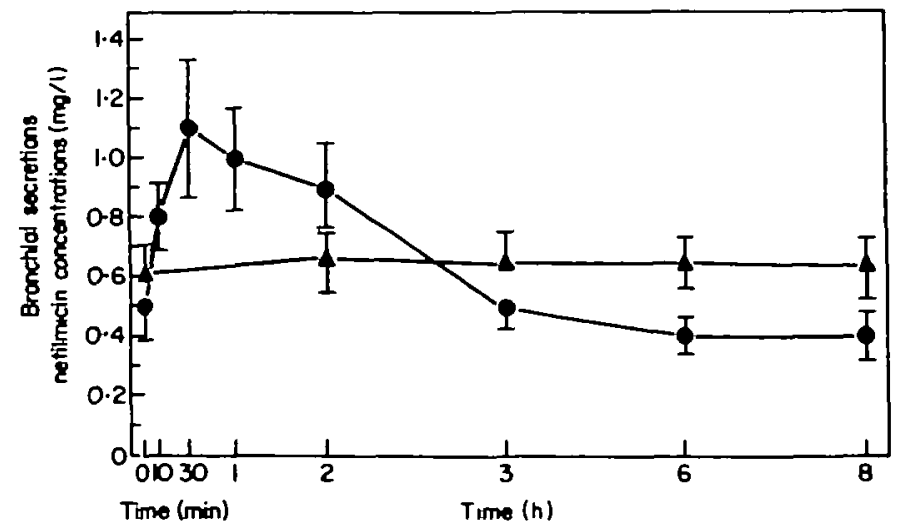

Figure 2. Bronchial secretions netilmicin levels after bolus injection (e) and during continuous infusion (A). 


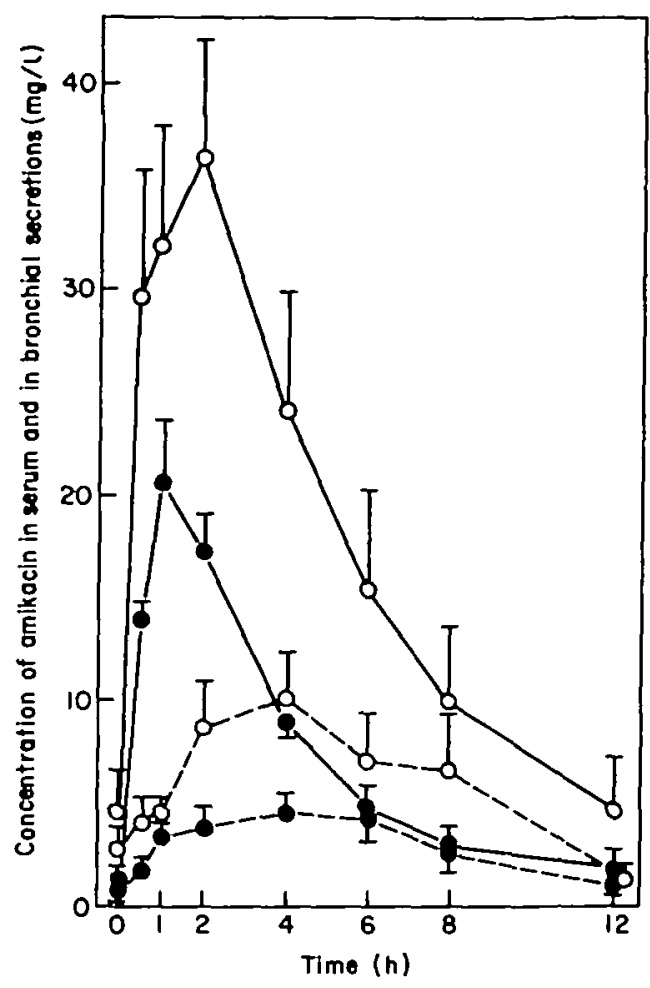

Figure 3. Bronchial secretions and serum amikacin levels after im administration. Serum: $7.5 \mathrm{mg} / \mathrm{kg}$

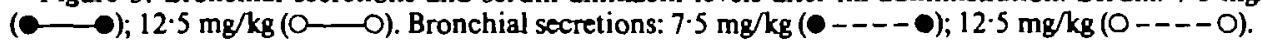

observed 6 and $12 \mathrm{~h}$ later were $7 \cdot 0 \pm 2 \cdot 1$ and $1 \cdot 1 \pm 0.5 \mathrm{mg} / \mathrm{l}$ respectively. With these two dosages, the percentages of penetration of amikacin into the bronchial lumen were similar $(42 \cdot 0$ and $36 \cdot 2 \%$ respectively).

Continuous injection of amikacin. The mean serum amikacin level was $12.8 \pm 1.4 \mathrm{mg} / \mathrm{l}$ (mean \pm S.E.) (Table I). The serum level of the drug was constant as indicated by little variations between samples taken at $2 \mathrm{~h}$ intervals. The mean bronchial secretions level was $2.0 \pm 0.4 \mathrm{mg} / \mathrm{l}$. There was a correlation between serum and bronchial secretions amikacin levels $(r=0.77, P<0.05)$. The percentage of penetration of the drug was $14.9 \%$. Only one patient out of six had adequate antibacterial activity in bronchial secretions $(1 / 8$, corresponding to an amikacin bronchial secretion level of $4 \mathrm{mg} / \mathrm{l}$ ). The five other patients had no satisfactory antipseudomonas activity and had lower amikacin levels in the bronchial secretions in spite of adequate serum levels of the drug and adequate serum bactericidal activity (Mombelli et al., 1982).

\section{Discussion}

Clinical experience indicates that the outcome of bronchial pulmonary infection could be related, among other factors, to the level of antimicrobial activity which is obtained in the bronchial secretions. Maesen et al. (1976), treated acute exacerbations of chronic bronchitis with increasing doses of bacampicillin: in their 
Table I. Antibiotic concentration and anti-Pseudomonas activity in serum and bronchial secretions during the continuous infusion of amikacin

\begin{tabular}{|c|c|c|c|c|c|c|c|}
\hline \multirow{3}{*}{$\begin{array}{l}\text { Patient } \\
\text { number }\end{array}$} & \multicolumn{4}{|c|}{ Amikacin levels (mg/) } & \multirow{3}{*}{$\begin{array}{c}\text { Bronchial } \\
\text { penetration } \\
\text { of amikacin } \\
(\%)\end{array}$} & \multirow{2}{*}{\multicolumn{2}{|c|}{$\begin{array}{l}\text { Bactericidal titre } \\
\text { against } P \text { s. aeruginosc } \\
\text { (median values) }\end{array}$}} \\
\hline & \multirow{2}{*}{\multicolumn{2}{|c|}{$\begin{array}{c}\text { Ser } \\
\text { Single } \\
\text { values at } \\
2 \mathrm{~h} \\
\text { intervals }\end{array}$}} & \multirow{2}{*}{ Mean } & \multirow{2}{*}{$\begin{array}{l}\text { Bronchial } \\
\text { secretions }\end{array}$} & & & \\
\hline & & & & & & Serum & $\begin{array}{l}\text { Bronchial } \\
\text { secretions }\end{array}$ \\
\hline 1 & $8 \cdot 2$ & $8 \cdot 4$ & $8 \cdot 3$ & $1 \cdot 3$ & $15 \cdot 7$ & $1: 4$ & $1: 2$ \\
\hline 2 & $14 \cdot 0$ & $13 \cdot 0$ & $13 \cdot 5$ & $1 \cdot 3$ & 9.6 & $1: 8$ & $1: 2$ \\
\hline 3 & $14 \cdot 0$ & $14 \cdot 0$ & $14 \cdot 0$ & $1 \cdot 5$ & $10 \cdot 7$ & $1: 8$ & $1: 2$ \\
\hline 4 & $10 \cdot 5$ & $8 \cdot 8$ & $9 \cdot 65$ & $1 \cdot 4$ & 14.5 & $1: 8$ & $1: 2$ \\
\hline 5 & 13 & 15 & 14 & $2 \cdot 3$ & 16.4 & $1: 4$ & $1: 2$ \\
\hline 6 & 18 & 15 & $17 \cdot 5$ & $4 \cdot 0$ & $22 \cdot 8$ & $1: 16$ & $1: 8$ \\
\hline Mean \pm S.E. & & & $12 \cdot 8 \pm 1 \cdot 4$ & $2.0 \pm 0.4$ & $14.9 \pm 1.9$ & & \\
\hline
\end{tabular}

study, the clinical and microbiological success of the treatment was related to the levels of ampicillin in the bronchial secretions. In a group of patients with acute bronchitis or pneumonia treated with amoxycillin, Stewart et al. (1974) showed a more favourable clinical outcome in the patients with a high sputum level of the drug than those with a low one. More recently, Klastersky et al. (1979) treated two groups of 20 tracheostomized patients with Gram-negative bronchopneumonia; sisomicin or a placebo was administered endotracheally to these patients and, in addition, all of them received systematically a combination of sisomicin and carbenicillin. A favourable clinical response was more frequent in the group of patients who received sisomicin endotracheally than in the group who received the placebo (77 vs 45\%) (Table II). The bronchial sisomicin level, $1 \mathrm{~h}$ after the endotracheal instillation, was more than $1050 \mathrm{mg} / \mathrm{l}$ in the sisomicin treated group and only $0.45 \mathrm{mg} / \mathrm{l}$ in the placebo group; the bactericidal activity of the bronchial secretions was $1 / 256$ or undetectable in the two groups, respectively. This last study suggests a relationship between the clinical outcome of Gram-negative pulmonary

Table II. Treatment of Gram-negative bronchopneumonia with endotracheal sisomicin (with sisomicin and carbenicillin iv)

\begin{tabular}{lcccc}
\hline & \multicolumn{2}{c}{ Placebo } & \multicolumn{2}{c}{ Sisomicin } \\
& No. patients & No. success & No. patients & No. success \\
\hline Total number of patients & 20 & $9(45 \%)^{*}$ & 18 & $14(77 \%)^{*}$ \\
\hline & $\begin{array}{c}\text { Bronchial } \\
\text { secretions }\end{array}$ & Serum & $\begin{array}{l}\text { Bronchial } \\
\text { secretions }\end{array}$ & Serum \\
\hline $\begin{array}{l}\text { Levels of sisomicin }(\mathrm{mg} / \mathrm{l}) \\
\text { (mean } \pm \text { S.E.) }\end{array}$ & $0.45 \pm 0.11$ & $1.04 \pm 0.25$ & $1051 \pm 271.5$ & $1.18 \pm 0.28$ \\
\hline \begin{tabular}{l} 
Bactericidal activity \\
\hline
\end{tabular} & 0 & $1 / 8$ & $1 / 256$ & $1 / 8$ \\
\hline
\end{tabular}

- $P<005$. 
infections, the bronchial level of the aminoglycoside and the bactericidal activity within the bronchial secretions. Thus, the bronchial level of the antibiotic and the resulting-bactericidal activity are satisfactory criteria to evaluate the potential effectiveness of a mode of administration of antibiotics for bronchopulmonary infection.

The basic problem of the respective effectiveness of intermittent or continuous administration of antibiotic is still unsolved; elsewhere in this issue, Barza reviews personal data and other information from the literature on this subject. A short comment about the work of Kozak et al. (1977) who compared bolus or prolonged infusion as determinants of the degree and the rate of penetration of gentamicin into intraperitoneally implanted capsules in rabbits is relevant. Their protocol was relatively similar to our study of the bronchial penetration of netilmicin with bolus or continuous injection. They injected $1.7 \mathrm{mg} / \mathrm{kg}$ of gentamicin as a rapid bolus injection or as a slow intravenous injection. During the first $2 \mathrm{~h}$ of the experiment the authors noted that the mean level of gentamicin in the intraperitoneal capsule was slightly but significantly higher after the bolus injection than after the prolonged infusion, but later the level became similar with the two modes of administration. During the first $6 \mathrm{~h}$ the areas under the curves for serum and capsule fluid, gentamicin levels obtained by rapid infusion were a little greater than those obtained by slow injection. These data are in accordance with our study on the bronchial penetration of netilmicin.

During the first $2 \mathrm{~h}$ the areas under the curves of netilmicin levels in bronchial secretions resulting from bolus injection were significantly greater than those following continuous infusion. The total areas under the curves corresponding to the complete $(8 \mathrm{~h})$ experiment were, however, identical with the two modes of administration. Similar conclusions were reached when areas under the curves in serum were studied. Thus, in the work of Kozak et al. (1977), as in ours, during the first $2 \mathrm{~h}$ of the experiment the amount of the antibiotic after the bolus injection at the site of the potential infection (intraperitoneal capsule or bronchial secretions) was significantly greater than with a continuous infusion. But over the total duration of the experiments the amount of antibiotic, at the sites studied, were almost identical with both modes of administration.

A basis of antibiotic therapy is to assure at the site of infection a drug level higher than the minimum inhibitory concentration of the pathogen. If one considers the sensitivity of most Enterobacteriacae and Ps. aeruginosa to aminoglycosides and the bronchial levels of these drugs after bolus or during continuous intravenous injection, it becomes clear that only the bolus injection is able to achieve, in the bronchial secretions, levels of antibiotics which are adequate to inhibit most strains. For netilmicin for example, administration of continuous infusion resulted in our experiment in levels in bronchial secretions that were subinhibitory for most pathogenic organisms responsible for bronchial infection in tracheostomized patients in our hospital. On the contrary, repeated bolus injections resulted in higher levels of netilmicin within the bronchial secretions that exceeded the MIC of most pathogens. As far as our experiments with repeated intramuscular injection and continuous infusion of amikacin were concerned the conclusions were similar: repeated injection resulted in higher bronchial levels of the drug which were inhibitory for most pathogens, than continuous infusion of similar doses, which resulted in irregular and lower levels and inconstant antibactericidal effects. 
It is therefore suggested that in order to obtain therapeutic levels of aminoglycosides within the bronchial secretions intermittent administration of high doses of aminoglycosides might be more effective than continuous infusion. Nevertheless, even the bronchial levels of antibiotics that result from bolus injections were not much higher than the inhibitory concentration for most pathogens. Since the concentration of antibiotics in the bronchial secretion might be important in the treatment of bronchopulmonary infection, endotracheal administration of aminoglycoside, in order to obtain high and sustained levels of antibiotics as well as an effective antibactericidal effect, might be indicated as an adjunct for the therapy of severe Gram-negative bacillary bronchopulmonary infections (Klastersky et al., 1979).

\section{Acknowledgements}

We thank Pr J. Brihaye for allowing us to study his patients. We are indebted to $M$. Husson and M. L. Bourguignon for their excellent technical assistance. We wish to express our thanks to the nursing staff of the Neurosurgical Care Unit of the Institute Jules Bordet for their invaluable help in taking care of the patients.

\section{References}

Bennett, J. V., Brodie, J. L., Benner, E. J. \& Kirby, W. M. M. (1966). Simplified, accurate method for antibiotic assay of clinical specimens. Applied Microbiology 14, 170-7.

Bergogne-Berezin, E., Even, P. \& Berthelot, G. (1978). Pharmacocinétique de l'amikacine dans les sécrétions bronchiques. Revue Française des Maladies Respiratoires 6, 385-92.

Klastersky, J., Meunier-Carpentier, F., Kahan-Coppens, L. \& Thys, J. P. (1979). Endotracheally administered antibiotics for Gram negative bronchopneumonia. Chest 75, 586-91.

Kozak, A. J., Gerding, D. N., Peterson, L. R. \& Hall, N. W. (1977). Gentamicin intravenous infusion rate: effect on interstitial fluid concentration. Antimicrobial Agents and Chemotherapy 12, 606-8.

McCrae, W. M., Raebum, J. A. \& Hanson, E. J. (1976). Tobramycin therapy of infections due to Pseudomonas aeruginosa in patients with cystic fibrosis: effects of dosage and concentration of antibiotic in sputum. Journal of Infectious Diseases 134, Suppl., 191-3.

Maesen, F. P. V., Beeuwkes, H., Davies, B. I., Buytendijk, H. J., Brombacher, J. P. \& Wessman, J. (1976). Bacampicillin in acute exacerbations of chronic bronchitis-a dose-range study. Journal of Antimicrobial Chemotherapy 2, 279-85.

Mombelli, G., Coppens, L., Thys, J. P. \& Klastersky, J. (1982). Anti-Pseudomonas activity in bronchial secretions of patients receiving amikacin or tobramycin as a continuous infusion. Antimicrobial Agents and Chemotherapy 19, 72-75.

Pennington, J. E. \& Reynolds, H. Y. (1973). Concentrations of gentamicin and carbenicillin in bronchial secretions. Journal of Infectious Diseases 128, 63-8.

Pennington, J. E. \& Reynolds, H. R. (1975). Pharmacokinetics of gentamicin sulfate in bronchial secretions. Journal of Infectious Diseases 131, 158-62.

Stewart, S. M., Anderson, I. M. E., Jones, G. R. \& Calder, M. A. (1974). Amoxycillin levels in sputum, serum and saliva. Thorax 29, 110-14.

Thys, J. P., Mouawad, E. \& Klastersky, J. (1979). Concentrations of netilmicin in bronchial secretions and in serum during intermittent versus continuous infusion. A crossover study in humans. Journal of Infectious Diseases 140,634.

Thys, J. P. \& Klastersky, J. (1980a). Inactivation of netilmicin and amikacin by leucocytes. 2nd Mediterranean Congress of Chemotherapy, Nice, p. 253.

Thys, J. P. \& Klastersky, J. (1980b). Penetration of amikacin in serum and in bronchial secretions. The role of the dosage. 2nd Mediterranean Congress of Chemotherapy, Nice, p. 144. 